\title{
Effects of peach or hybrid rootstocks on growth and cropping of two cultivars of peach trees (Emeraude and Zephyr)
}

\author{
Claude Bussi, Jacques Besset, Thierry Girard
}

Inra-UERI,

Domaine de Gotheron, 26320 Saint-Marcel-lèsValence, France
* Correspondence and reprints

Received 27 December 2001 Accepted 17 April 2002

Fruits, 2002, vol. 57, p. 249-255 (C) 2002 Cirad/EDP Sciences All rights reserved DOI: 10.1051/fruits:2002022

Resumen Español, p. 255

\section{Effects of peach or hybrid rootstocks on growth and cropping of two cultivars of peach trees (Emeraude and Zephyr).}

Abstract - Introduction. Rootstock is an important consideration for a productive peach orchard, especially in a replanting situation. A peach and two hybrid rootstocks, grafted with an early and a late-season peach cultivar, were planted and their growth compared. The experimental area had been used since 1970, for two generations of successive peach crops. Materials and methods. Emeraude (early-season) and Zephyr (late-season) were grafted onto GF 305 (peach rootstock), GF 677 and Cadaman ${ }^{\circledR}$ Avimag (hybrid rootstocks), and were planted in a split-plot experimental design. Fruit yield and vegetative growth were assessed annually. Results. Vegetative growth was greater with the hybrid rootstocks than with the peach rootstock. Fruit production was higher with Cadaman than with GF 677, which was higher than with GF 305. Yield differences associated with rootstocks were greater with Emeraude in comparison with Zephyr, as suggested by the rootstock $\times$ cultivar interaction. Discussion. Compared to the previous peach plantation on the same land, the differences observed in this current experiment, between the peach rootstock GF 305 and the hybrid rootstock GF 677, widened, suggesting a replanting decline with the peach rootstock. In the given conditions, the hybrid rootstock Cadaman appeared to be better suited than GF 677 to improving peach production.

France / Prunus persica / rootstocks / varieties / growth control / yields / soil sickness

\section{Incidence de porte-greffes pêcher ou hybrides sur la croissance et la production de deux cultivars de pêcher (Émeraude et Zéphyr).}

Résumé - Introduction. Le choix du porte-greffe est un facteur important à considérer pour assurer le succès d'un verger de pêcher, et cela plus particulièrement dans le cas d'une replantation. Par conséquent, un porte-greffe pêcher et deux porte-greffes hybrides, greffés avec une variété de pêcher précoce et une variété de pêcher tardive, ont été plantés sur une parcelle expérimentale préalablement occupée par deux générations successives de pêchers ; l'effet des porte-greffes a été comparé. Matériel et méthodes. Un porte-greffe pêcher (GF 305) et deux porte-greffes hybrides (GF 677 et Cadaman), associés avec Émeraude (cultivar précoce) et Zéphyr (cultivar tardif), ont été plantés selon un dispositif split-plot. Le rendement en fruits et la croissance végétative des arbres ont été estimés pour chacun des différents traitements. Résultats. La croissance végétative des pêchers a été meilleure avec les porte-greffes hybrides qu'avec le porte-greffe pêcher. La production de fruits obtenue avec Cadaman a été supérieure à celle obtenue avec l'autre porte-greffe hybride (GF 677) qui, elle-même, a été supérieure à celle obtenue avec le porte-greffe pêcher (GF 305). Ces différences de rendement induites par le porte-greffe ont été accentuées lors de l'utilisation du cultivar précoce (Émeraude) par rapport au greffage du cultivar tardif (Zéphyr), comme l'a indiqué l'observation d'une interaction significative porte-greffe $\times$ cultivar. Discussion. En se référant à une précédente plantation effectuée sur la même parcelle expérimentale, les différences observées lors de notre expérimentation entre le porte-greffe pêcher GF 305 et le porte-greffe hybride GF 677 ont été accrues ; cela suggérerait une dégénérescence (fatigue de sol) due à la replantation avec le porte-greffe pêcher. Par ailleurs, dans nos conditions expérimentales, Cadaman est apparu être un porte-greffe hybride mieux adapté que GF 677 pour améliorer la production de pêches.

France / Prunus persica / porte-greffe / variété / contrôle de croissance / rendement / fatigue du sol 


\section{Introduction}

Currently, many rootstocks are available for peach $[1,2]$. This wide range of rootstocks for peach cultivars provides many choices for solving soil, climate and phytosanitation problems [3, 4]. Rootstock affects vegetative growth, leaf nutrient content and yield of the scion cultivar [5-7]; reciprocally, the response of different peach cultivars to a given rootstock may vary significantly [8]. Therefore, experiments using different cultivars to compare the suitability of different peach rootstocks should be performed in order to evaluate the cultivar $\times$ rootstock interaction.

In the Middle Rhone Valley of France, previous experiments have been conducted to check and compare different scion cultivar and rootstock combinations. However, these trials generally consisted of comparing associations of scion cultivars with different rootstocks including few repetitions, but without a complete experimental design [9]. This paper is a report on an experiment performed using an early-season and a lateseason peach cultivar associated with a peach and two hybrid rootstocks, the experimental arrangement consisting of a splitplot with 40 trees of the same combination rootstock-cultivar.

Moreover, a replanting situation (third generation peach) was chosen to take into account the peach tree decline [10], rootstock choice being a determining factor in this case. In the previous generation of trials [11], an early-season and a late-season cultivar were grafted onto peach rootstocks (including GF305) and onto a hybrid rootstock (GF 677). In the current experiment, GF 305 and GF 677 were once more compared and another hybrid rootstock (Cadaman ${ }^{\circledR}$ Avimag) was also tested [12].

\section{Materials and methods}

\subsection{Orchard plantation}

This study was conducted in a peach tree orchard planted in 1995 at the Gotheron Experimental Station of the French Institut
National de la Recherche Agronomique (INRA) near Valence in the Middle Rhone Valley of France. Before planting this trial, the land had been used for two successive generations of peach cultivation since 1970 [13]. The soil was stony alluvial with 15\% clay, 30\% silt and 54\% sand and was considered to be particularly suitable for peach tree cropping [14].

The area of the experimental orchard was approximately 0.5 ha and the trees were spaced $4 \mathrm{~m}$ in each row with $5 \mathrm{~m}$ between rows. These distances were thought to be large enough not to restrict the growth possibilities of even the most vigorous rootstocks. They also corresponded to the distance between rows used for the previous generations of peach trees. The trees were thus replanted in the same rows so they would intensify any possible replanting problem. However, the roots from the previous plantation were carefully removed before planting, so disruption of the present experiment would be minimised.

\subsection{Experimental arrangement and analysis}

Cultivars represented the whole plot in a split-plot experimental design. Two peach cultivars were planted: Emeraude (earlyseason) and Zephyr (late-season).

Rootstocks represented the split-plot. The rootstocks used were the peach rootstock GF 305, and two hybrid rootstocks: GF 677 (almond $\times$ peach) and Cadaman ${ }^{\circledR}$ Avimag (Davidiana $\times$ peach).

The treatments were arranged in four blocks with five trees in each experimental unit. Moreover, two repetitions of each elementary parcel were disposed, so that there were $40(4 \times 5 \times 2)$ trees of the same combination rootstock-cultivar. Guard rows were planted around the plots of the experimental area.

For statistical analysis, means were compared using the Newman and Keuls test [15]. Concerning fruit yield and average fruit weight, the years were included in the analysis, as a split-split plot. 


\subsection{Orchard management}

A trickle irrigation system with drippers (two emitters at $1 \mathrm{~m}$ on either side of each tree) with a discharge rate of $30 \mathrm{~L} \cdot \mathrm{h}^{-1}$ was installed. Irrigation was scheduled according to a previous experiment [16]. These irrigations represented $50 \%$ of potential evapo-transpiration (PET) and 100\% of PET during the 3 weeks before harvest. $\mathrm{K}, \mathrm{P}, \mathrm{Mg}$ and $\mathrm{Ca}$ were added before planting to meet the requirements of the orchard after soil analyses [17]. In addition, $K$ was added every year after planting, because the first application of $\mathrm{K}$ was not enough to last the entire period of the experiment. $\mathrm{N}$ was also applied every year at the rate of $100 \mathrm{~kg} \cdot \mathrm{h}^{-1}$. Weeds in the tree rows were controlled mechanically by hoeing in the first two years, and with one application of diuronsimazine in subsequent years. Occasionally glyphosate was applied when needed. Between rows, grass was allowed to grow naturally.

\subsection{Experimental measurements}

Hand-thinning was conducted in May to space fruit (10 to 15$) \mathrm{cm}$ apart along the fruiting shoots in order to ensure suitable fruit size. Each cultivar was harvested at the firm-ripe stage in three or more pickings as required, and harvest weights were recorded. The average weight of fruit was determined on a representative sample (about 30\% of the total harvest). Plant growth was evaluated every year in winter by measuring the circumference of the tree trunk $30 \mathrm{~cm}$ from the ground.

\section{Results}

\subsection{Plant growth}

For both cultivars, trunk circumferences were greater with hybrid rootstocks than with the peach rootstock (figure 1). Five years after planting, the tree vigour (measured by trunk circumference) brought about by GF 305 was 22\% and 28\% lower than the tree vigour caused by GF 677 for the

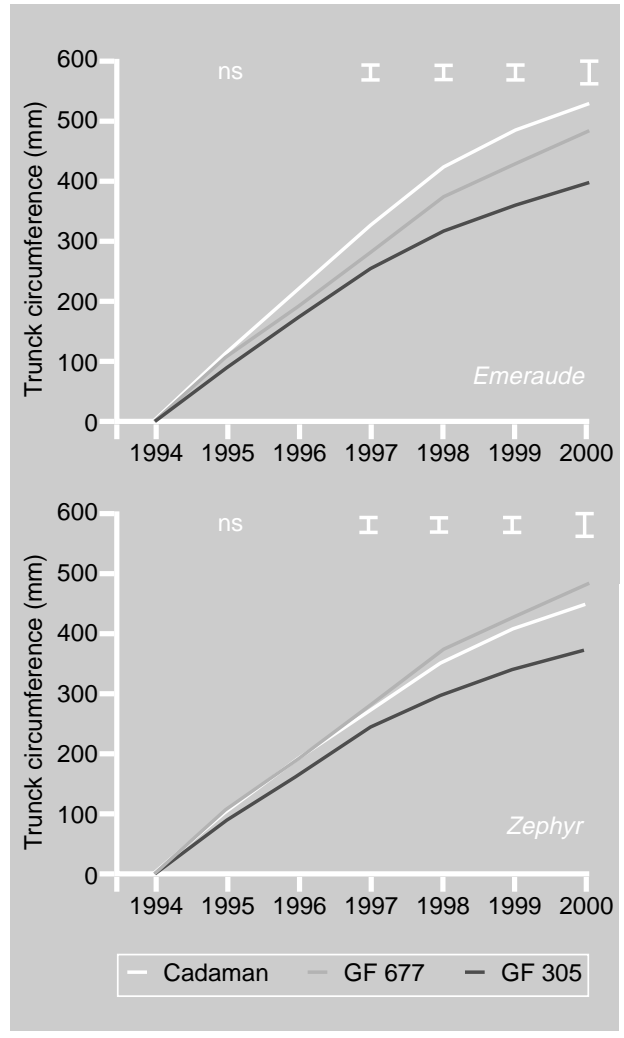

Emeraude and Zephyr cultivars, respectively. Compared to GF 677, the tree vigour produced with Cadaman was higher (+9\%) for Emeraude and lower (-8\%) for Zephyr and the rootstock $\times$ cultivar interaction was significant from 1997 to 2000.

\subsection{Fruit yield}

Fruit yield was generally higher with Zephyr than with Emeraude (table I). However, the highest yield was obtained with Emeraude in 1999, revealing a year $\times$ cultivar interaction (significant according to the statistical test).

From 1997 to 2000, there were differences in yield between the three rootstocks (figure 2). These differences were significant in 1999 and 2000 with Emeraude and in 1997 and 2000 with Zephyr. The general trend was that the yield with Cadaman was higher than that with GF 677, which was in turn higher than that produced with GF 305 . These results were confirmed by the cumulative
Figure 1.

Plant growth evaluated by measuring the trunk circumferences $30 \mathrm{~cm}$ from the ground for two peach cultivars (Emeraude and Zephyr) grafted onto three different rootstocks: peach (GF 305) and hybrid (GF 677, Cadaman), in the Middle Rhone Valley of France. Vertical bars denote the least significant digit (LSD) at $p=0.05$; ns: not significant. 
Table I.

Fruit yield (kg per tree) as a function of the peach cultivar and the year, for a peach tree orchard planted in 1995 in the Middle Rhone Valley of France. Means have been calculated for three rootstocks used (GF 305, peach rootstock; GF 677 and Cadaman, hybrid rootstocks).

\begin{tabular}{lcc} 
Year & \multicolumn{2}{c}{ Cultivar } \\
& Emeraude & Zephyr \\
& & \\
1997 & $10.0 \mathrm{e}$ & $12.1 \mathrm{e}$ \\
1998 & $10.2 \mathrm{e}$ & $18.9 \mathrm{~d}$ \\
1999 & $63.6 \mathrm{a}$ & $56.8 \mathrm{~b}$ \\
2000 & $51.2 \mathrm{c}$ & $55.5 \mathrm{~b}$
\end{tabular}

Data followed by different letters are significantly different at $p=0.05$; these letters refer to the comparison between the two cultivars and for the different years.

\section{Figure 2.}

Tree yield in two peach cultivars (Emeraude and Zephyr) grafted onto three different rootstocks: peach (GF 305) and hybrid (GF 677, Cadaman), in the Middle Rhone Valley of France. Vertical bars denote the least significant digit (LSD) at $p=0.05 ;$ ns: not significant.

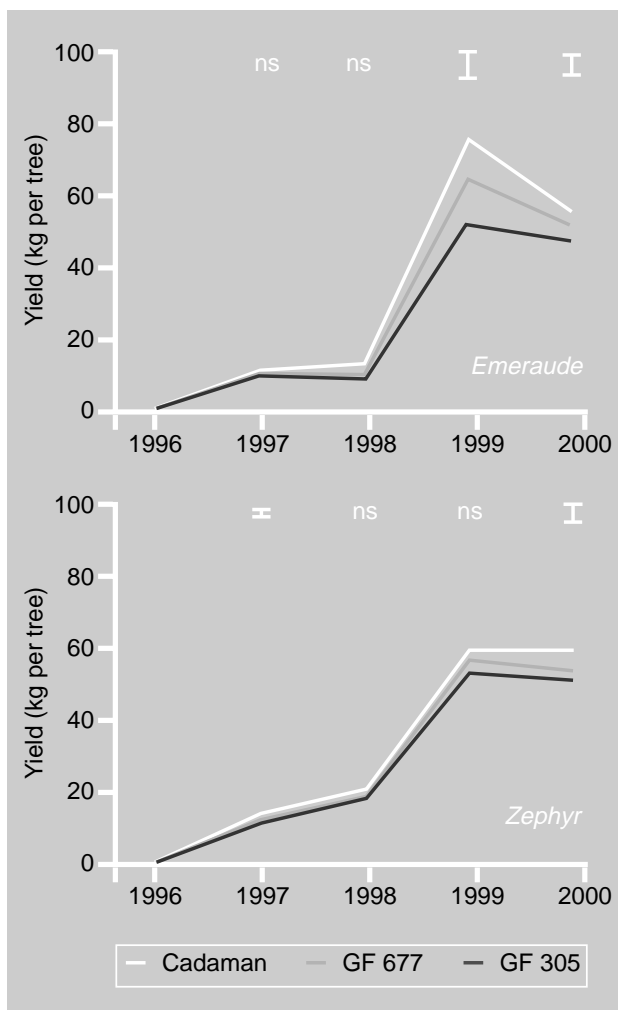

yields (figure 3). Compared to GF 677, the cumulative yield obtained in 2000 with GF 305 was lower when grafted with Emeraude $(-17 \%)$ and with Zephyr (-5\%); compared to Cadaman, the cumulative yield obtained with GF 677 was lower with Emeraude $(-12 \%)$ and with Zephyr (-10\%).
Moreover, a significant rootstock $\times$ cultivar interaction was detected in 1999. There were greater differences in fruit yield between the rootstock treatments with Emeraude (45\%) than with Zephyr (13\%).

Thus, the principal finding was the lower yield of the scions on peach GF 305 rootstock, particularly with the Emeraude scion cultivar. Cadaman gave the highest yields for both cultivars.

\subsection{Average fruit weight}

The differences in average fruit weight according to the rootstock treatments were rather small (figure 4); they were significant only in 1999 with Emeraude and in 2000 with Zephyr. However, the trend was a higher average fruit weight produced by trees on Cadaman (table II): from 1997 to 2000, the mean was nearly 3\% (Emeraude) and 5\% (Zephyr) higher with Cadaman than with GF 305, respectively. Furthermore, the average fruit weight obtained with GF 305 was very close to that obtained with GF 677.

Average fruit weight was quite high, between 150 and $230 \mathrm{~g}$. The highest was observed in 1998, when yields were low (figure 4); the lowest occurred in 1999, when yields were high.

\section{Discussion}

\subsection{Peach (GF 305) and hybrid (GF 677) rootstock in a replanting situation}

Compared to trees on GF 677, a lower trunk circumference resulted from GF 305 in the present study $(-25 \%)$ than that reported in a previous trial $(-13 \%)$ observed on the same land (figure 1) [11]. This suggests that, with GF 305, there may have been a replanting-related decline in tree performances. Peach tree replanting decline when using peach rootstocks has previously been observed [3, 18]. Toxicity due to the exudation of biochemical inhibitors present in the roots of the genus Prunus persica may have been involved [19]. Furthermore, for the current and the previous experiments, 
the lower vegetative growth of trees on GF 305, in comparison with GF 677, was more drastic when associated with the lateseason cultivar $(-23 \%)$ than with the earlyseason cultivar (-16\%) (figure 1) [11]. The hypothesis has already been made that lateseason cultivars are often less vigorous than early cultivars, probably because carbohydrate storage over the winter is greater in the early cultivars as a result of a longer period of time after fruit harvest to build up reserves [20].

Lower (-11\%) fruit yield was also observed with GF 305 compared to GF 677 (figure 3). As in the case of vegetative growth, the difference in yield was more significant than that observed $(-5 \%)$ in a previous trial, which confirmed that there may have been a peach tree replanting decline. However, this reduction in yield particularly affected the early-season cultivar $(-12 \%$ against $-4 \%$ for the late-season cultivar), which was the reverse of vegetative growth data, as mentioned above. This supports the hypothesis of competition between vegetative growth and fruit growth for the available photosynthates [21]. The major period of vegetative growth in peach occurs during the spring and early summer and this would coincide more with stage III of fruit growth in the early cultivar than in the late cultivar. Thus, the direct competition between fruit and shoot growth would be greater in the early cultivar [22, 23].

Average fruit weight did not markedly differ between GF 305 and GF 677 when considering the results year by year (figure 4). This is the consequence of the handthinning done in spring, according to the tree fruit-bearing capacity. Thus, differences between treatments affected the fruit number per tree, rather than the average fruit weight.

In short, during the third generation of peaches in the same orchard land, the peach rootstock (GF 305) appeared to bring about a greater limitation in tree vigour and fruit yield. In our conditions, this replanting decline was apparently reduced by using the hybrid GF 677 rootstock.

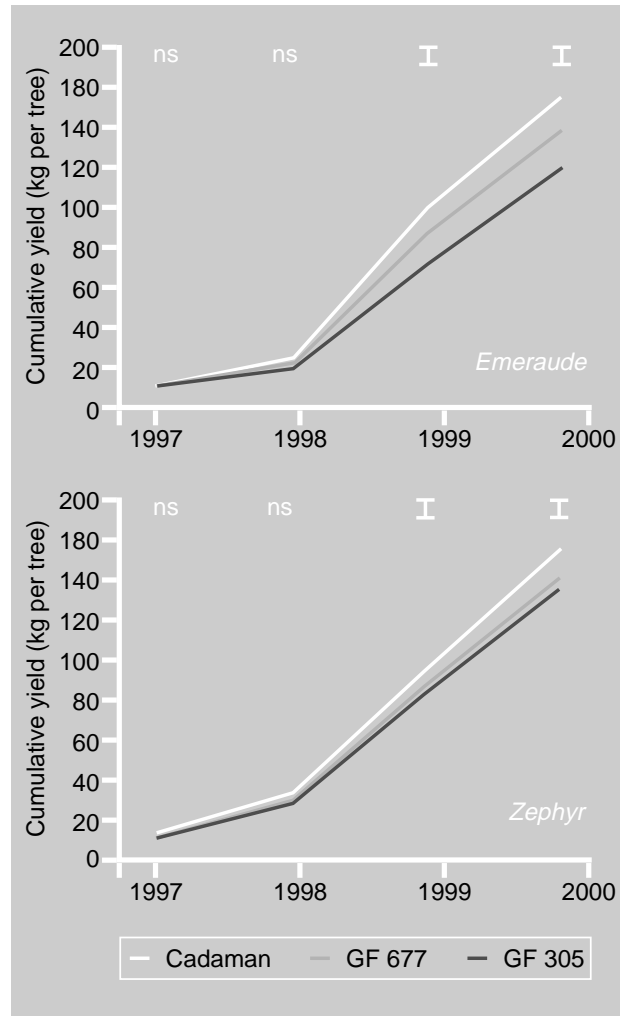

Figure 3.

Cumulative tree yield in two peach cultivars (Emeraude and Zephyr) grafted onto three different rootstocks: peach (GF 305) and hybrid (GF 677, Cadaman), in the Middle Rhone Valley of France. Cumulative harvest weights are equal to sums of the yields from the orchard plantation until the considered year. Vertical bars denote the least significant digit (LSD) at $p=0.05$; ns: not significant.

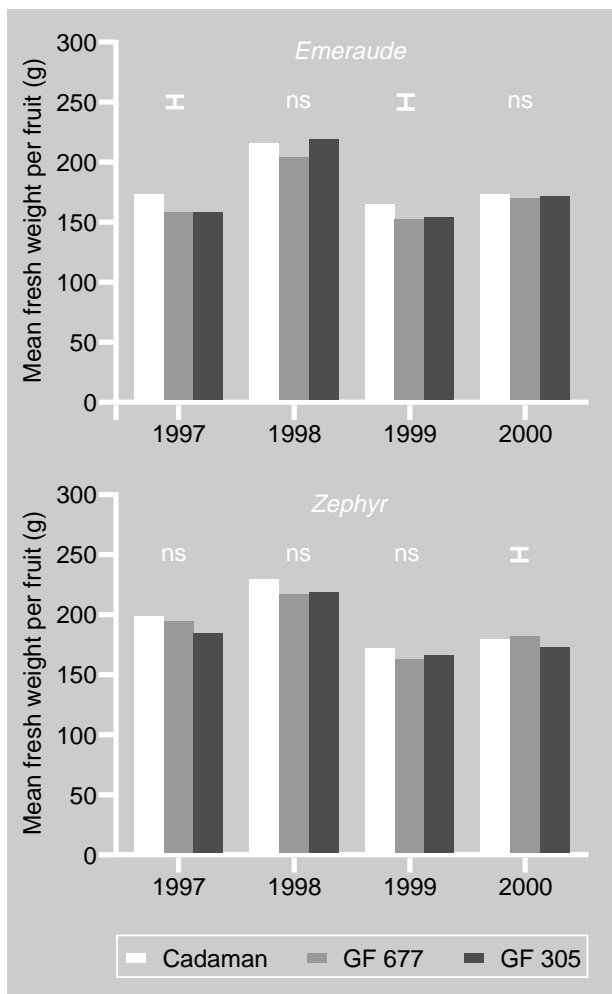

Figure 4.

Average peach weight in two peach cultivars (Emeraude and Zephyr) grafted onto three different rootstocks: peach (GF 305) and hybrid (GF 677, Cadaman), in the Middle Rhone Valley of France. Vertical bars denote the least significant digit (LSD) at $p=0.05$; ns: not significant. 
Table II.

Average fruit weight $(\mathrm{g})$ as a function of the peach cultivar and the rootstock (GF 305, peach rootstock; GF 677 and Cadaman, hybrid rootstocks), for a peach tree orchard planted in 1995 in the Middle Rhone Valley of France. Means have been calculated for four years $(1997,1998,1999,2000)$.

\begin{tabular}{lcc} 
Rootstock & \multicolumn{2}{c}{ Cultivar } \\
& \multicolumn{1}{c}{ Emeraude } & Zephyr \\
& $175 \mathrm{~d}$ & $184 \mathrm{bc}$ \\
GF 305 & $170 \mathrm{e}$ & $188 \mathrm{~b}$ \\
GF 677 & $180 \mathrm{c}$ & $193 \mathrm{a}$ \\
Cadaman & \\
$\begin{array}{l}\text { Data followed by different letters are significantly different at } p=0.05 \text {; these letters } \\
\text { refer to the comparison between the two cultivars and for the different rootstocks. }\end{array}$ \\
\\
\end{tabular}

With the early-season cultivar (Emeraude), vegetative growth was $9 \%$ greater with the Cadaman rootstock, compared to the GF 677 roostock; with the late-season cultivar (Zephyr), this vegetative growth was $8 \%$ less (figure 1). This significant rootstock $\times$ cultivar interaction may suggest that the Cadaman rootstock is particularly appropriate for early-season peach cultivar. Otherwise, it may be just a genetic difference unrelated to harvest time.

Cadaman resulted in greater yield (by 10\%) compared to GF 677 (figures 2, 3). Average fruit weight was also slightly higher with Cadaman $(+5 \%$ and $+3 \%$ in Emeraude and Zephyr, respectively) (table II). Thus, in our experimental conditions, Cadaman significantly increased the peach production capacity, compared to GF 677 and GF 305. This trend has previously been observed [12], but not as clearly as in this experiment.

It is probable that our replanting conditions contributed to differences produced by the rootstocks. With this third generation of peach orchard on the same land, peach growth and production appeared to decline on GF 305, when compared to GF 677. Cadaman seemed to be better adapted to a replanting situation than GF 677. However, the experimental peach orchard was only 6 years old. These results have to be confirmed in the years to come.

\section{References}

[1] Durner E.F., Goffreda J.C., Rootstock induced differences in flower bud phenology in peach, J. Am. Soc. Hort. Sci. 117 (5) (1992) 690-697.

[2] Glucina P.G., Mills R.S., Manson P.J., Comparison of the growth, yield, fruit size, and survival of Golden Queen peach on seven rootstocks, New Zeal. J. Crop. Hort. 20 (1992) 297-303.

[3] Layne R.E.C., Prunus rootstock affects longterm orchard performance of Redhaven peach on Brookston clay loam, HortScience 29 (3) (1994) 167-171.

[4] Caruso T., Giovannini D., Livererani A., Rootstock influences the fruit mineral, sugar and organic acid content of a very early ripening peach cultivar, J. Hortic. Sci. 71 (6) (1996) 931-937.

[5] Okie W.R., Ta Tao P.I., 101686 affects bloom date and tree size of Sunprince peach, Fruit Var. J. 44 (2) (1990) 87-89.

[6] Beckman T.G., Okie W.R., Meyers S.C., Rootstocks affect bloom date and fruit maturation of Redhaven peach, J. Am. Soc. Hort. Sci. 117 (3) (1992) 377-379.

[7] Franco J.A., Abrisqueta J.M., Hernansaez A., Root development of almond rootstocks in a young almond orchard under trickle irrigation as affected by almond scion cultivar, J. Hortic. Sci. 70 (4) (1995) 597-607.

[8] Tubbs F.R., Growth relations of rootstock and scion in apple, J. Hortic. Sci. 55 (2) (1980) 181-189.

[9] Edin M., Garcin A., Influence intrinsèque du porte-greffe sur le comportement de la variété chez le pêcher : interactions croissancefacteurs de production, in: $8^{\mathrm{e}}$ colloque sur recherches fruitières, Bordeaux, France, 7-8 décembre 1988, Pont-de-la-Maye, France, Inra/CTIFL, 1988, pp. 195-206.

[10] Layne R.E.C., Weaver G.M., Jackson H.O., Stroud F.D., Influence of peach seedling rootstocks on growth, yield and survival of peach scion cultivars, J. Am. Soc. Hort. Sci. 101 (1976) 568-572.

[11] Bussi C., Huguet J.G., Besset J., Girard T., Rootstock effects on the growth and fruit yield of peach, Eur. J. Agron. 4 (3) (1995) 387-393.

[12] Edin M., Garcin A., Un nouveau porte-greffe du pêcher Cadaman ${ }^{\circledR}$ Avimag, Arboric. Fruit. 475 (1994) 20-23. 
[13] Bussi C., Besset J., Duc A., Incidence du porte-greffe sur la croissance et la fructification du pêcher, Fruits 50 (2) (1995) 125-132.

[14] Bornand M., Étude pédologique dans la vallée du Rhône, Centre de recherches agronomiques du Midi, Inra Éditions, Montpellier, France, 1968.

[15] Pearce S.G., Field experimentation with fruit trees and other perennial plants, in: Technical communication No. 23 of the Commonwealth Bureau of Horticulture and Plantation Crops, Commonwealth Agricultural Bureau, East Malling, Maidstone, Kent, 1953.

[16] Bussi C., Huguet J.G., Besset J., Girard T., Irrigation scheduling of an early maturing peach cultivar using tensiometers and diurnal changes in stem diameter, Fruits 54 (1999) 57-66.

[17] Bussi C., Élements pour l'interprétation d'une analyse de sol. Application à la fertilisation des arbres fruitiers sur un sol de diluvium alpin, Internal note Inra-SRIV, Saint-Marcellès-Valence, France, 1984, $21 \mathrm{p}$.
[18] Sharpe R.H., Breeding peach rootstock for the Southeastern United States, HortScience 9 (1974) 362-363.

[19] Reilly C.C., Edwards J.H., Okie W.R., Isolation and characterization of endogenous inhibitors of nitrate reductase of peach and their distribution in the genus Prunus, J. Plant Nutr. 9 (10) (1986) 1335-1351.

[20] Dejonc T.M., Doyle J.F., Day K.R., Seasonal patterns of reproductive and vegetative sink activity in early and late maturing peach cultivar, Physiol. Plant. 71 (1987) 83-88.

[21] Mitchell P.D., Chalmers D.J., The effect of reduced water supply on peach tree growth and yield, J. Am. Soc. Hort. Sci. 107 (1982) 853-856.

[22] Chalmers D.J., Van Den Ende B., A reappraisal of the growth and development of peach fruit, Aust. J. Plant Physiol. 2 (1975) 623-634.

[23] Genard M., Bruchou C., A functional and exploratory approach to studying growth, J. Am. Soc. Hort. Sci. 118 (2) (1993) 317-323.

\section{Incidencia de portainjertos de melocotonero o híbridos en el crecimiento y producción de dos cultivares de melocotonero (Emeraude y Zephyr).}

Resumen - Introducción. La elección del portainjerto es un factor importante a tener en cuenta para garantizar el éxito de un huerto de melocotoneros y, especialmente, en el caso de una replantación. Por consiguiente, un portainjerto melocotonero y dos portainjertos híbridos, injertados con una variedad de melocotón temprano y una variedad de melocotón tardío, se plantaron en una parcela experimental previamente ocupada por dos generaciones sucesivas de melocotoneros y se comparó el efecto de los portainjertos. Materiales y métodos. Un portainjerto melocotonero (GF 305) y dos portainjertos híbridos (GF 677 y Cadaman), asociados con Emeraude (cultivar precoz) y Zephyr (cultivar tardío), fueron plantados según un diseño de parcelas subdivididas. Se estimó el rendimiento en frutas y el crecimiento vegetativo de los árboles con cada uno de los tratamientos. Resultados. El crecimiento vegetativo de los melocotoneros fue mejor con los portainjertos híbridos que con el portainjerto melocotonero. La producción de fruta obtenida con Cadaman fue superior a la obtenida con el otro portainjerto híbrido (GF 677) que, a su vez, fue superior a la obtenida con el portainjerto melocotonero (GF 305). Estas diferencias de rendimiento inducidas por el portainjerto se acentuaron en la utilización del cultivar precoz (Emeraude) con relación al injerto del cultivar tardío (Zephyr), como indicó la observación de una interacción significativa portainjerto $\times$ cultivar. Discusión. Con respecto a una plantación anterior efectuada en la misma parcela experimental, las diferencias observadas, en la experimentación presentada, entre el portainjerto melocotonero GF 305 y el portainjerto híbrido GF 677 se incrementaron; esto podría indicar una degeneración (cansancio del suelo) debido a la replantación con el portainjerto melocotonero. Por otra parte, en nuestras condiciones experimentales, Cadaman se mostró como un portainjerto híbrido mejor adaptado que GF 677 para mejorar la producción de melocotón.

Francia / Prunus persica / portainjertos / variedades / control del crecimiento / rendimiento / fatiga del suelo 